\title{
ANALISIS KEKUATAN DAN STABILITAS STRUKTUR SISTEM PARKIR OTOMATIS BERBANTUAN SOFTWARE
}

\author{
Eko Reinaldo ${ }^{1)}$, Agustinus Purna Irawan ${ }^{1)}$ dan Frans Jusuf Daywin ${ }^{2)}$ \\ ${ }^{1)}$ Program Studi Teknik Mesin Fakultas Teknik Universitas Tarumanagara, Jakarta \\ ${ }^{2)}$ Teknik Pertanian Institut Pertanian Bogor, Bogor \\ e-mail: reisoulmate@gmail.com
}

\begin{abstract}
Automatic parking system is a car parking system which moves the vehicle from the parking lot entrance to the parking space automatically with no drivers. Automatic car parking system accepts the load's structure which should be done by the calculation and the structural strength analysis to get a strong and stable structure with expected safety level. The analysis in this thesis is undertaken by using of structure analysis software. Resulted of structural strength analysis which has been done in this thesis is strong and stable automatic car parking system structure design.
\end{abstract}

Keywords: automatic parking system, analysis, structure analysis software.

\section{PENDAHULUAN}

Salah satu permasalahan di kotabesars seperti Jakarta yang sering diperbincangkan akhirakhir ini adalah mengenai keterbatasan lahan parkir serta pelarangan parkir kendaraan bermotor dipinggir jalan sehingga semakin menyulitkan pemilik kendaraan bermotor terutama kendaraan bermotor beroda empat (mobil) untuk memarkirkan kendaraannya.

Tetapi keterbatasan lahan parkir ini tidak menyurutkan minat untuk membeli mobil pribadi yang jumlahnya semakin meningkat dari tahun ke tahun. Menurut data dari Dinas Perhubungan, pertumbuhan jumlah kendaraan pribadi beroda empat di Jakarta mencapai 1.117 unit per hari atau sekitar 9\% per tahunnya [1].

Pertumbuhan jumlah mobil di kota besar seperti Jakarta yang tumbuh dengan sangat pesat, tentu membuat kebutuhan akan jumlah tempat parkir di gedung-gedung tempat aktivitas warga kota yang harus semakin banyak jumlah tempat parkirnya. Seperti dapat dilihat bahwa gedung parkir konvensional sekarang ini sudah tidak dapat lagi menampung kendaraan yang jumlahnya telah melebihi kapasitas yang dapat ditampung oleh gedung parkir itu sendiri sehingga menyebabkan waktu pengemudi dalam mencari lahan parkir terbuang percuma karena kesulitan dalam mencarilahan parkir yang kosong di dalam gedung parkir.

Oleh karena itu, dibutuhkan solusi untuk permasalahan parkir yang terbatas di Jakarta ini. Solusi yang paling mudah adalah dengan memperbesar gedung parkir sehingga kapasitas gedung parkir semakin banyak. Tetapi memperbesar gedung parkir tentu akan memakan lahan yang semakin besar dimana kita mengetahui lahan kosong di Jakarta semakin sulit untuk dicari. Solusi kedua adalah dengan membangun gedung parkir dengan menggunakan sistem parkir otomatis dimana sistem ini nantinya dapat memarkirkan kendaraan penumpang beroda empat langsung ketempat parkir yang kosong. Sistem parkir otomatis ini, sangat efektif dari segilahan karena lahan tempat jalan mobil menuju ke slot parkir dapat dieliminasi sehingga tidak dibutuhkan lagi jalan menuju ketempat parkir karena perjalanan ketempat parkir yang biasanya kendaraan langsung di bawa pengemudi ke tempat parkir sekarang langsung dibawa oleh sistem parkir otomatis ini dan juga sistem ini akan sangat efektif dalam segi waktu terhadap warga kota besar yang selalu memperhitungkan setiap waktu dalam kegiatannya.

Pada sistem parkir otomatis ini menampung beban mobil pada strukturnya. Sehingga perlu dilakukan perhitungan kekuatan struktur sistem parkir otomatis untuk mendapatkan sistem parki rotomatis yang yang dapat bekerja dengan baik dan memiliki kekuatan struktur yang memadai sehingga dapat mencapai tingkat keselamatan yang diharapkan.

Masalah yang harus diselesaikan dalam analisis struktur sistem parkir otomatis ini adalah mengenai kekuatan dan stabilitas struktur sistem parkir otomatis, bahan yang digunakan untuk 
mendapatkan struktur yang kuat dan stabil pada sistem parkir otomatis, dan jenis kendaraan yang bisa ditampung sistem parkir otomatis.

Batasan masalah meliputi perhitungan dan analisis kekuatan dan kestabilan pada struktur sistem parkir otomatis, perhitungan berat maksimal kendaraan yang dapat ditampung oleh struktur sistem parkir otomatis, dan bahan yang digunakan pada struktur sistem parkir otomatis.

Tujuan dari perancangan ini adalah untuk mendapatkan struktur sistem parkir otomatis yang kuat, aman, dan stabil.

\section{METODOLOGI PERANCANGAN}

Dalam melakukan analisis perhitungan kekuatan dan stabilitas sistem parkir otomatis ini, pertama-tama dilakukan penetapan jenis sistem parkir otomatis yang akan dirancang. Setelah menetapkan jenis sistem parkir otomatis yang akan dirancang, selanjutnya dilakukan pemilihan material yang akan digunakan dalam sistem parkir otomatis ini.

Material utama dari sistem parkir otamatis ini adalah stainless steel, 440c. Pemilihanjenis material stainless steel, 440c karena memiliki sifat tahan korosi serta material yang memiliki sifat yang kuat dan kaku. Untuk lead screw dipilih material stainless steel karena sifat tahan korosi serta memiliki sifat material yang kuat dan mudah untuk dilakukan proses permesinan. Untuk palet pemindah menggunakan material Zirconia Toughened Alumina (ZTA) karena material ini memiliki sifat sangat kaku dan ringan sehingga tidak menimbulkan defleksi jika digunakan sebagai material palet pemindah.

Setelah dilakukan pemilihan material, selanjutnya dilakukan langkah desain sistem parkir otomatis yang menggunakan bantuan software CAD/CAE 3 dimensi. Selanjutnya dilakukan perhitungan kecepatan putar maksimal sistem parkir otomatis ini.

Perhitungan kecepatan putar sistem parkir otomatis bertujuan untuk mengetahui kecepatan putar maksimal sistem parkir otomatis karena sistem parkir otomatis ini bekerja berputar pada sistem kerjanya. Putaran pada sistem parkir otomatis mengakibatkan adanya frekuensi kerja pada sistem parkir otomatis. Oleh karena itu, harus dilakukan perhitungan kecepatan putar sistem parkir otomatis serta perhitungan frekuensi kerja sistem parkir otomatis.

Setelah itu, langkah selanjutnya dilakukan perhitungan kekuatan power screw yang digunakan sebagai sistem pergerakan pada sistem parkir otomatis ini. Power screw yang kuat dan stabil adalah power screw yang ketika bekerja, tegangan keseluruhan yang bekerja pada power screw tersebut berada di bawah tegangan izin yang dimiliki oleh spesifikasi material yang digunakan $(\sigma<\bar{\sigma})$. Selanjutnya dilakukan perhitungan pemilihan bantalan yang bertujuan untuk mengetahui bantalan yang dipilih benar-benar sesuai dengan kerja yang akan dilakukan oleh bantalan tersebut. Pada sistem parkir otomatis ini, bantalan yang digunakan adalah jenis bantalan ball bearing.

Setelah melakukan perhitungan kekuatan komponen pada sistem parkir otomatis, langkah selanjutnya dilakukan simulasi kekuatan dan stabilitas struktur sistem parkir otomatis dengan menggunakan bantuan software Autodesk Inventor Professional 2012. Simulasi yang dilakukan terdiri dari 2 tahap. Untuk menganalisis kekuatan struktur terhadap beban yang diberikan dilakukan analisis struktur static. Hasil dari analisis struktur static harus lebih kecil dari tegangan izin yang dimiliki oleh material yang digunakan sehingga mencapai tingkat keamanan yang diinginkan.

Tahap kedua dalam proses analisis struktur yaitu modal analisis. Modal analisis bertujuan untuk mengetahui frekuensi pribadi yang dimiliki sistem parkir otomatis. Frekuensi pribadi sistem parkir otomatis ini dibandingkan dengan frekuensi sistem yang bekerja yang didapatkan dari perhitungan putaran pada sistem parkir otomatis ini. Frekuensi sistem yang bekerja harus lebih kecil dan tidak boleh sama dengan frekuensi pribadi sistem parkir otomatis. Sistem parkir otomatis dikatakan stabil jika kedua syarat tersebut terpenuhi. 


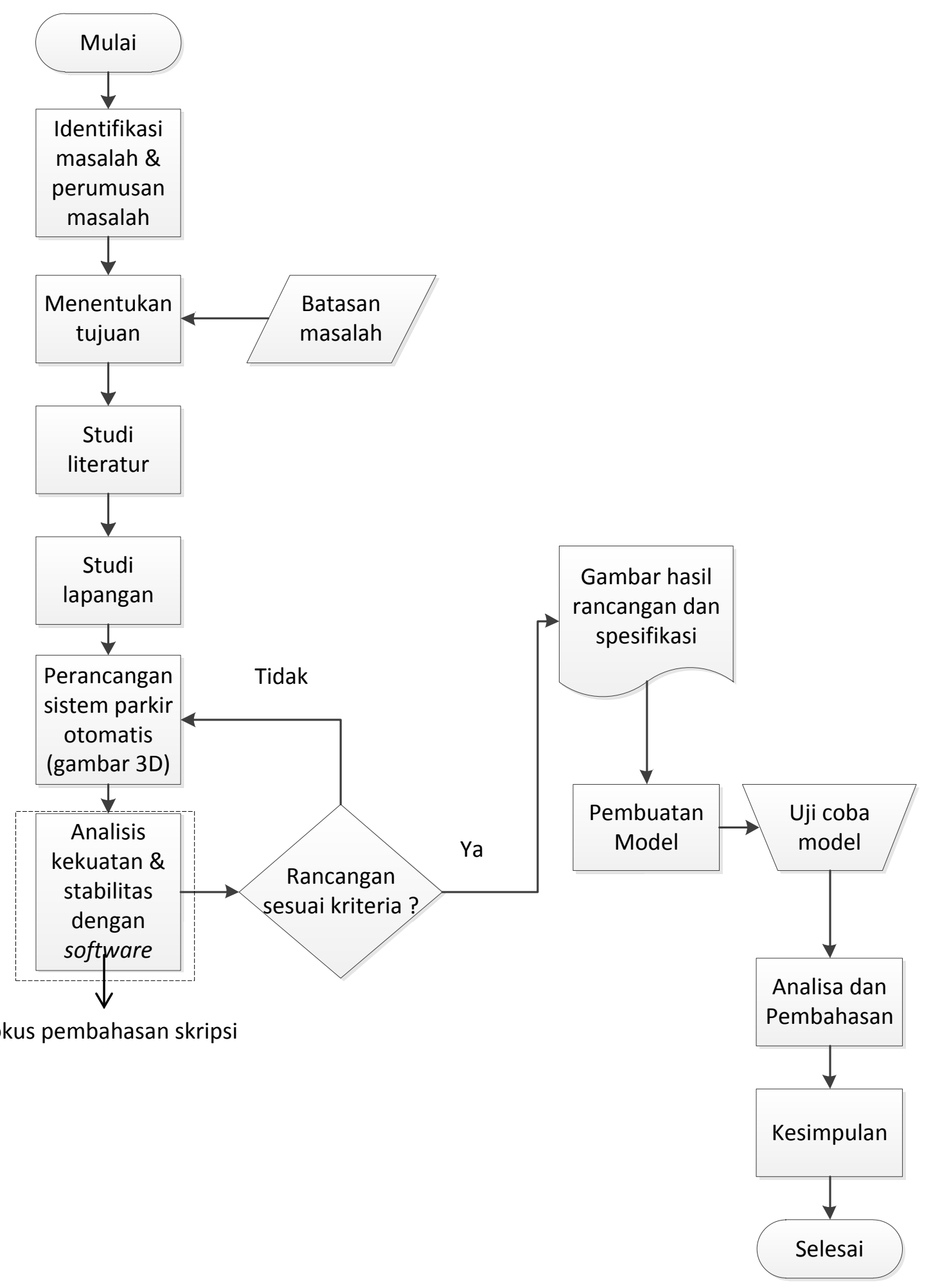

Gambar 1. Diagram alir perancangan.

\section{HASIL DAN PEMBAHASAN}

Perancangan sistem parkir otomatis meliputi tahapan perancangan teknik, penggambaran secara detail tiap komponen yang digunakan, dan setelah itu dilanjutkan perakitan komponen menjadi satu bagian sistem parkir otomatis yang utuh. Hasil perancangan sistem parkir otomatis tersebut bisa dilihat pada Gambar 2.

Setelah langkah perancangan struktur sistem parkir otomatis, dilakukan simulasi kekuatan dan kestabilan struktur sistem parkir otomatis dengan hasil seperti pada Tabel 1. 


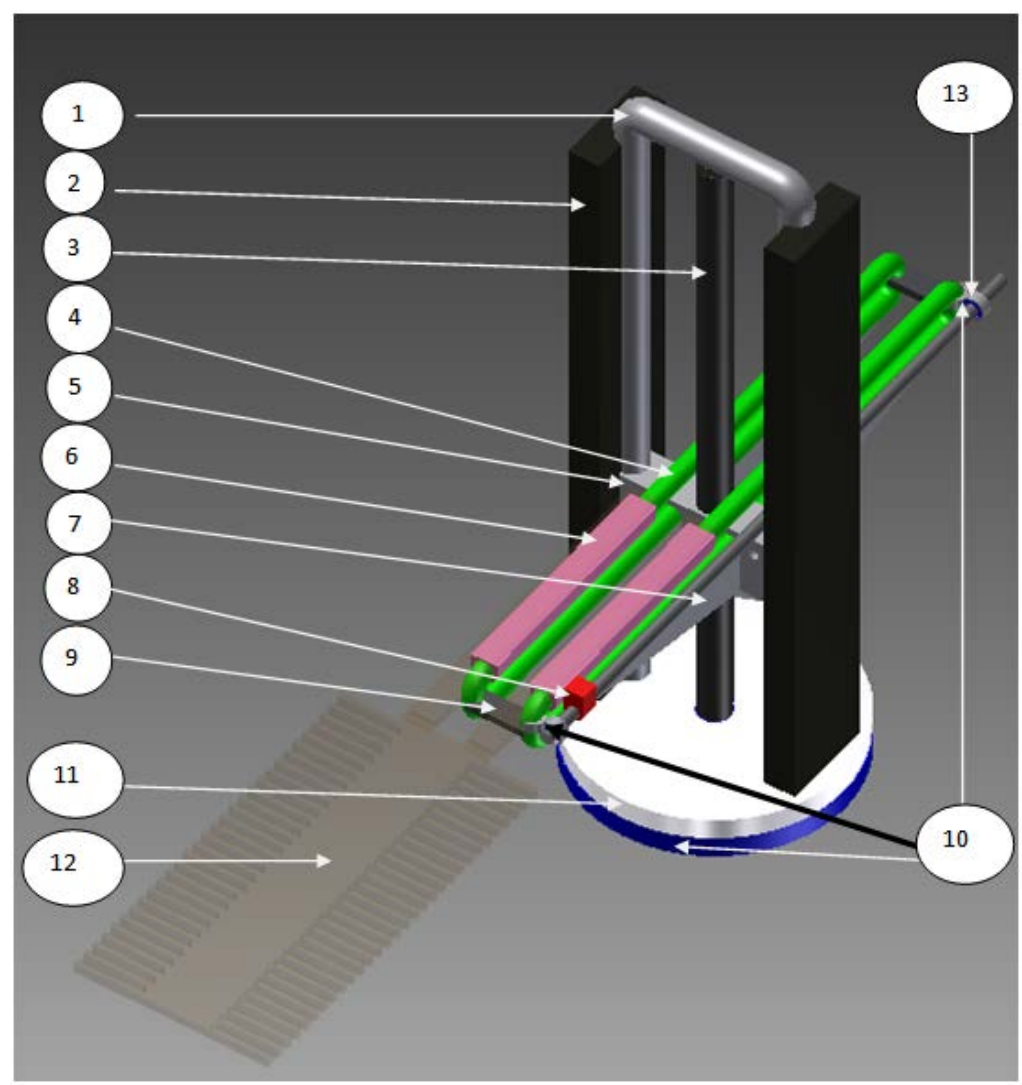

Keterangan Gambar:

Gambar 2. Hasil gabungan
1) Tiang Elevator
2) Penguat Tiang Elevator
3) Power Screw Vertikal
4) Slider Horizontal
5) Pemegang Elevator
6) Pemegang Slider
7) Penguat Batang Slider

8) Sambungan Pemegang Slider

9) Penyeimbang Batang Slider

10) Bantalan

11) Piringan Putar

12) Sisir Pemindah

13) Pemegang Bantalan Power Screw Horizontal

Tabel 1. Hasil analisis struktur sistem parkir otomatis

\begin{tabular}{|c|c|c|c|c|}
\hline No. & Material & $\begin{array}{c}\text { Kekuatan } \\
\text { Luluh }(M P a)\end{array}$ & $\begin{array}{c}\sigma_{\text {aktual } \mathrm{M}(\mathrm{M}} \\
(\mathrm{MPa})\end{array}$ & Keterangan \\
\hline 1. & Stainless steel & 250 & 66,09 & Kuat \\
\hline 2. & Stainless steel, 440c & 689 & 66,09 & Kuat \\
\hline 3. & $\begin{array}{l}\text { Zirconia Toughened } \\
\text { Alumina (ZTA) }\end{array}$ & 400 & 66,09 & Kuat \\
\hline
\end{tabular}

Dari hasil analisis struktur sistem parkir otomatis didapatkan hasil bahwa struktur sistem parkir otomatis kuat karena tegangan yang bekerja pada struktur tersebut lebih kecil dari tegangan izin yang diperbolehkan. Selanjutnya hasil simulasi modal analisis dapat dilihat pada Gambar 4.

Dari hasil simulasi modal analisis, didapatkan bahwa frekuensi pribadi aktual sistem parkir otomatis dalam kondisi berputar didapatkan pada $f 3$ dan $f 4$. Dari simulasi diketahui bahwa frekuensi pribadi yang sesuai dengan pergerakan memutar sistema dalah $f 3=7,15 \mathrm{~Hz}$ dan $f 4=7,24 \mathrm{~Hz}$ sedangkan frekuensi sistem $=0,25 \mathrm{~Hz}$ sehingga syarat kestabilan sistem parkir otomatis terpenuhi karena frekuensi sistem lebih kecil dan tidak sama dengan besar frekuensi pribadi. 


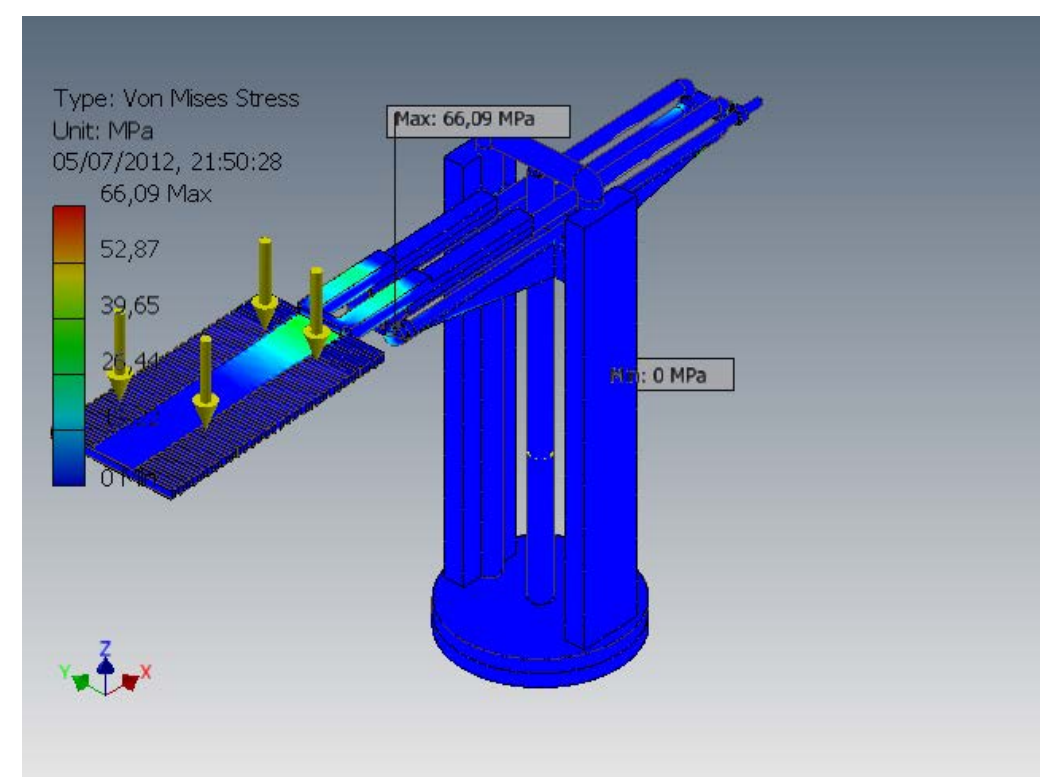

Gambar 3. Hasil analisis struktur sistem parkir otomatis.

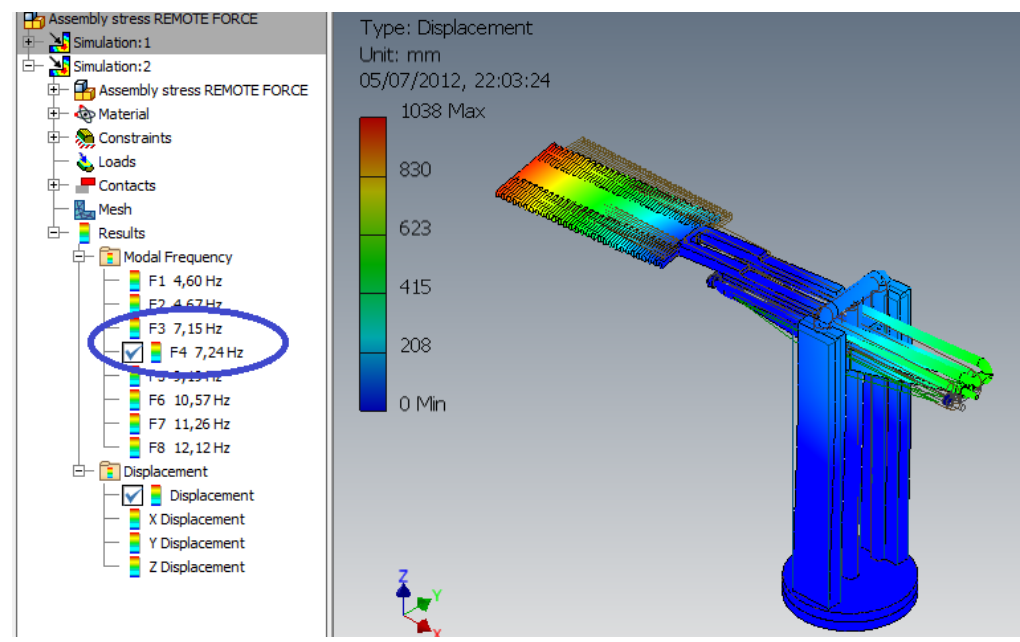

Gambar 4. Hasil analisis modal struktur sistem parkir otomatis

Selanjutnya dilakukan uji coba pembuatan prototyping sistem parkir otomatis dengan 8 slot parkir yang terbagi dalam 2 lantai.

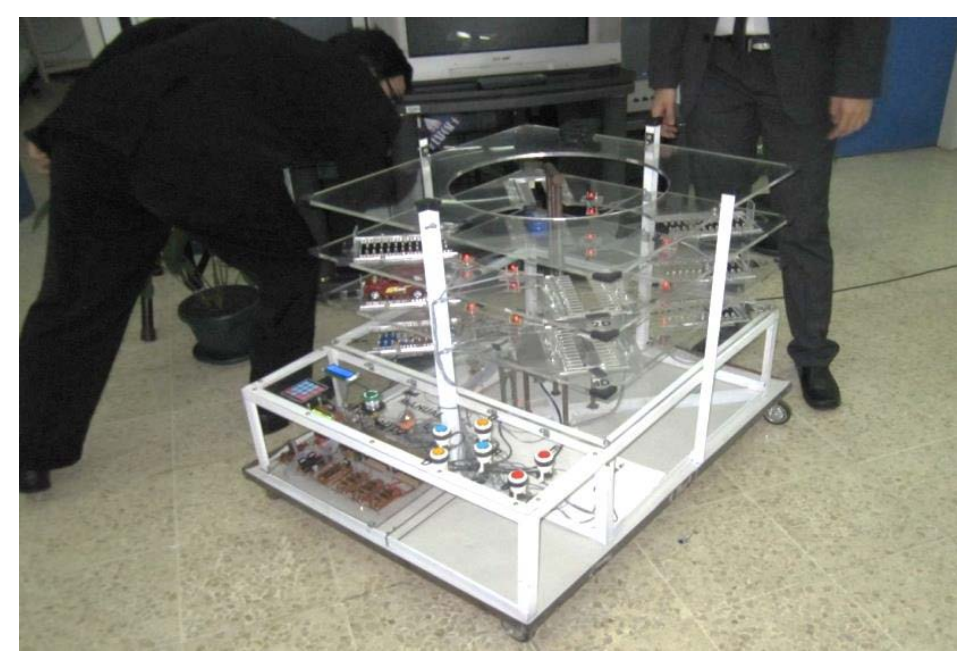

Gambar 5. Prototyping 


\section{KESIMPULAN DAN SARAN}

Berdasarkan pengamatan, perhitungan dan analisis yang telah dilakukan dengan menggunakan software Autodesk Inventor Professional, maka diambil kesimpulan bahwa hasil rancangan dapat digunakan sebagai struktur sistem parkir otomatis, karena melalui perhitungan dan analisis tegangan yang bekerja, struktur yang dirancang memenuhi kriteria keamanan dan kekuatan serta kestabilan sistem parkir otomatis.

Dari hasil perancangan didapatkan juga beberapa masukan baru, yaitu dimensi Power Screw yang digunakan terlalu besar karena tegangan yang bekerja pada screw sangat kecil dibandingkan tegangan yang diizinkan, pada bagian konstruksi sisir pemindah, harus diberikan suatu penguat kontruksi karena dibagian ini terjadi konsentrasi tegangan yang paling besar

\section{DAFTAR PUSTAKA}

[1]. http://www.tribunnews.com/2011/07/20/pertumbuhan-mobil-dan-motor-di-jakarta-1130 unitper-hari (29 februari 2012)

[2]. Khurmi R.S. dan Gupta J.K. A Textbook Of Machine Design. New Delhi: Eurasia Publishing House (PVT.) LTD. 2005

[3]. Diktat IPB. Tegangan Normal dan TeganganGeser.

[4]. Autodesk Inventor Professional 2012 Getting Started.

[5]. http://yefrichan.wordpress.com/2010/05/22/perancangan-teknik/. (06 Maret 2012).

[6]. Pahl and Beitz. Engineering Desaign: A Systematic Approach. http://dp2m.umm.ac.id/files/file/ARSIP\%20DOKUMEN\%20RISTEK/Metode_Desain_PAH L-BEITZ.doc. ( 04 Maret 2012)

[7]. http://mediaanakindonesia.wordpress.com/2011/06/01/parkir-paling-canggih-dan-modernada-di-rscm/ (06 Maret 2012).

[8]. Winarsih, Indra., Mahendra, Reza. Sistem parkir otomatis menggunakan RFID berbasiskan mikro kontroler AT 89S51.Universitas Trisakti.2009

[9]. Yulianti, Catur, Ria. Struktur Prategang. Pusat Pengembangan Bahan Ajar Universitas Mercu Buana. pksm.mercubuana.ac.id/.../11048-2-31257067214 (16 Juni 2012)

[10]. Dahlan, Dahmir. Diktat Kuliah Elemen Mesin Universitas Tarumanagara. Universitas Tarumanagara. 2009

[11]. Kelly, Graham S. The Fundamental of Mechanical Vibration. McGraw Hill. 2000

[12]. Suhendi, Yendi. 2012. Analisa Kekuatan dan Stabilitas Struktur Kincir Angin Tipe Vertical Axis Dengan Software Autodesk Inventor Profesional 2012, belum publikasi, tesis S1 Fakultas Teknik Universitas Tarumanagara.

[13]. http://matweb.com/search/QuickText.aspx?SearchText=stainlees\%20steel (15 Juni 2012)

[14]. Purna Irawan, Agustinus. Diktat Kuliah Statika Struktur Universitas Tarumanagara. Universitas Tarumanagara. 2008 